\title{
ANALISIS PEMASARAN TANDAN BUAH SEGAR KELAPA SAWIT DI KECAMATAN PUTRI HIJAU KABUPATEN BENGKULU UTARA
}

\author{
Marketing Analysis of Palm Oil Fresh Fruit Bunch in Putri Hijau \\ District, Bengkulu Utara Regency
}

\author{
Eko Sumartono, Redy Badrudin, Melli Suryanty dan Agus Rohman \\ Department of Agricultural Socio-Economics, Faculty of Agriculture, University of \\ Bengkulu \\ Correspondent Author: eko_sumartono@unib.ac.id
}

\begin{abstract}
This research was conducted in the District Putri Hijau of Bengkulu Utara. The aims of this research are to: 1) Identify the marketing channel of fresh fruit bunch of oil palm, 2) Calculate the amount of marketing margin of oil palm fresh fruit bunch in each marketing agencies. This research area sampling method was selected by using purposive sampling. The farmers sampling method was selected by using purposive sampling. The marketing agencies and palm oil mill was selected by using snowball sampling. The numbers of sampling afarmers 41, traders 6, farmer groups 3, and palm oil mill 1. Data consisted of primary and secondary data. The results of this study were: there were three marketing channel. Channel I from farmers to traders and then to the palm oil mill, the channel II is from farmer to farmer groups and then to the palm oil mill, channel III, from farmers directly to palm oil mill. The highest value of marketing margin obtained by traders the village of Karang Tengah and Kota Bani of IDR 206.00 / Kg and the lowest marketing margin obtained by farmer group in the village of Kota Bani IDR $13.20 / \mathrm{kg}$.
\end{abstract}

Keyword : Palm oil, marketing chennels, marketing margin, profit marketing

\section{PENDAHULUAN}

Indonesia merupakan sebuah negara kepulauan yang memiliki lahan potensial untuk pertanian. Salah satu komoditas petanian yang dikembangkan di Indonesia adalah perkebunan kelapa sawit. Kelapa sawit memiliki banyak keunggulan salah satunya adalah kedudukannya sebagai komoditas ekspor nasional. Permintaan kelapa sawit pun terus meningkat sejalan dengan perkembangan teknologi dalam mengolahnya. Hal tersebut mengakibatkan komoditas kelapa sawit terus di kembangkan dan perkebunannya terus di perluas. Salah satu usaha pemerintah dalam mengembangkan perkebunan sawit adalah memperluas lahan perkebunan, Pemerintah terus melaksanakan targetnya hingga laju perluasan kebun sawit kini sudah mencapai 800 ribu hektar per tahun (Asih Putri, 2010).

Perkebunan di Provinsi Bengkulu dibagi menjadi 3 yaitu perkebunan rakyat, perkebunan negara dan perkebunan swasta. Luas perkebunan kelapa sawit 309.100 ha (BPS, 2013). Provinsi Bengkulu memiliki 9 Kabupaten dan 1 kota, salah satunya adalah Kabupaten Bengkulu Utara. Berdasarkan data yang ada diketahui bahwa luas areal tanaman kelapa sawit di Kabupaten Bengkulu Utara seluas 31.312 ha (BPS, 2013).

Di Bengkulu Utara setelah dibukanya perkebunan- perkebunan berskala besar dan dengan berdirinya pabrik sebagai pengolah hasil perkebuan dapat membuka wawasan bagi petani yang berdomisili di sekitar perkebunan tersebut, sehingga terciptalah perkebunan rakyat sebagai akibat positif dari teknologi yang dibawa oleh pembangunan pertanian perkebunan tersebut. Salah satu komoditi perkebunan yang semakin banyak diminati masyarakat adalah perkebunan kelapa sawit, hal ini terbukti dari tidak tertampungnya lagi tandan buah segar (TBS), sebagai hasil produksi yang melonjak tajam dari membanjirnya 
perkebunan kelapa sawit rakyat. Tak dapat disangkal, minyak sawit telah menjadi tulang punggung ekonomi bagi sebagian besar rumah tangga di Provinsi Bengkulu. Banyak penggunaan lahan dan konversi komoditas diubah menjadi perkebunan kelapa sawit. Hal ini menyebabkan ekonomi sangat tinggi ketergantungan rumah tangga terhadap minyak kelapa sawit (Sukiyono, dkk; 2017).

Di Kecamatan Putri Hijau dalam jual beli tandan buah segar yang telah berjalan pada petani kelapa sawit terdapat perbedaan saluran pemasaran dari produsen sampai konsumen. Dalam hal ini petani adalah sebagai produsen dan pabrik adalah konsumen tandan buah segar. Perbedaan saluran pemasaran tersebut akan mempengaruhi harga yang diterima oleh petani sehingga berpengaruh pada penerimaan petani. Petani sebagai produsen umumnya menerima harga yang relatif lebih rendah dibandingkan dengan harga yang dibayarkan konsumen. Hal ini dikarenakan terjadinya rantai pemasaran serta tingginya biaya pemasaran pada tiap lembaga pemasaran. Tingginya biaya pada tiap lembaga pemasaran itu antara lain dipengaruhi oleh berbagai faktor diantaranya proses pengangkutan dari lahan sampai ke pinggir jalan, transportasi, kerusakan, atau tingginya keuntungan yang ingin diperoleh pada lembaga pemasaran.

Penelitian pemasaran tandan buah segar kelapa sawit di Kecamatan Putri Hijau Kabupaten Bengkulu Utara bertujuan untuk mengetahui bentuk saluran pemasaran tandan buah segar kelapa sawit yang ada di Kecamatan Putri Hijau dan untuk mengetahui besar margin pemasaran tandan buah segar kelapa sawit yang ada di Kecamatan Putri Hijau Kabupaten Bengkulu Utara.

\section{METODE PENELITIAN}

\section{Penentuan Lokasi}

Penelitian ini dilakukan di Kecamatan Putri Hijau, Kabupaten Bengkulu Utara. Metode penentuan daerah penelitian dilakukan secara purposive sampling yang artinya secara sengaja karena Kabupaten Bengkulu Utara merupakan salah satu sentra produksi kelapa sawit rakyat terbesar kedua di Bengkulu setelah Kabupaten Muko-muko (Badan Pusat Statistik Provinsi Bengkulu,2013). Adapun pertimbangan pemilihan Kecamatan Putri Hijau adalah karena kecamatan tersebut memiliki luas lahan dan produksi kelapa sawit kelima tertinggi di Kabupaten Bengkulu Utara (Dinas Perkebunan Kabupaten Bengkulu Utara,2013) dan kecamatan tersebut mencakup desa yang di dalamnya mayoritas masyarakat adalah petani kelapa sawit dan terdapat beberapa variasi saluran pemasaran tandan buah segar. Dengan demikian diharapkan dapat mewakili tempat yang menjadi tujuan penelitian. Penelitian ini dilakukan pada bulan Mei sampai Juni 2016.

\section{Metode Pengambilan Data}

Data yang digunakan dalam penelitian ini adalah data primer dan data sekunder. Data primer adalah data yang diperoleh melalui daftar pertanyaan (Kuissioner) yang telah disiapkan, dengan teknik wawancara langsung kepada lembaga pemasaran dan petani kelapa sawit. Data sekunder adalah data yang diperoleh dari kepustakaan melalui sumbersumber yang telah dikeluarkan oleh pihak yang terkait.

\section{Penentuan Sampel}

Responden dalam penelitian ini adalah petani yang memiliki usahatani kelapa sawit yang sudah berproduksi. Pengambilan sampel wilayah (desa) dilakukan dengan metode 
Purposive Sampling. Dari 9 desa yang ada di Kecamatan Putri Hijau diambil 2 desa secara sengaja atau $20 \%$, yaitu Desa Karang Tengah dan Desa Kota Bani dengan pertimbangan kedua desa tersebut memiliki luas lahan dan jumlah usahatani kelapa sawit terbanyak di Kecamatan Putri Hijau. Jumlah populasi dalam penelitian ini yaitu sebanyak 444 orang petani (BPP, Kec. Putri Hijau, 2015) kemudian diambil sebanyak 41 sampel.

Pengambilan sampel untuk petani kelapa sawit dilakukan dengan menggunakan rumus Slovin (Nazir, 1988) dengan Margin Error responden ini ditetapkan sebanyak 15\%. Selanjutnya secara purposive responden tersebut terdiri dari masing-masing desa dapat diketahui masing-masing sampel tersebut adalah sebagai berikut:

Tabel 1. Penentuan Sampel menggunakan Slovin dengan purposive sampling

\begin{tabular}{llccc}
\hline No & \multicolumn{1}{c}{ Desa } & Luas lahan $(\mathrm{Ha})$ & Jumlah Petani & Jumlah sampel (n) \\
\hline 1 & Desa Karang Tengah & 559.89 & 253 & 23 \\
2 & Desa Kota Bani & 400.26 & 191 & 18 \\
\hline & Jumlah & 960.15 & 444 & 41 \\
\hline
\end{tabular}

Sumber : Hasil olahan Data Sekunder

Besar Responden:

$$
n=\frac{N}{1+N e} 2
$$

Keterangan:

$$
\begin{array}{ll}
\mathrm{n} & \text { : Sampel } \\
\mathrm{N} & \text { : Populasi } \\
\mathrm{E} & \text { : Margin Error }(15 \%) \\
& n=\frac{444}{1+444(0,15)} 2=40,40=41
\end{array}
$$

Sehingga jumlah sampel petani kelapa sawit yang digunakan dalam penelitian ini ialah sebesar 41 orang petani.

Sampel lembaga pemasaran yang terlibat dalam pemasaran tandan buah segar sampai kepada konsumen (pabrik) ditentukan dengan metode snow ball sampling, yakni penentuan sampel lembaga pemasaran yang mula-mula berdasarkan informasi dari petani responden, berikutnya berdasarkan lembaga pemasaran yang ditunjuk oleh petani responden, dan seterusnya sampai ke konsumen.

\section{Metode Analisis Data}

\section{Bentuk Saluran Pemasaran}

Metode analisis yang digunakan untuk mengetahui bentuk saluran pemasaran tandan buah segar kelapa sawit dijelaskan secara deskriptif. Yaitu dengan menggambarkan pola saluran pemasaran tandan buah segar dari petani (produsen) sampai kepada konsumen (pabrik CPO) yang terletak di tingkat kecamatan. (Sudiyono, 2002).

\section{Marjin Pemasaran}

Marjin pemasaran merupakan selisih harga ditingkat konsumen dan harga ditinggkat produsen. Untuk menghitung marjin dari setiap lembaga pemasaran digunakan rumus (Azzaino, 1983) :

$\mathrm{Mp}=\mathrm{Pr}-\mathrm{Pf}$ atau $\mathrm{Mp}=\mathrm{Bp}+\mathrm{Kp}$

Keterangan:

$\mathrm{Mp}=$ Marjin pemasaran $(\mathrm{Rp} / \mathrm{kg})$ 
$\operatorname{Pr}=$ Harga ditingkat konsumen $(\mathrm{Rp} / \mathrm{kg})$

$\mathrm{Pf}=$ Harga ditingkat produsen $(\mathrm{Rp} / \mathrm{kg})$

Bp $=$ Biaya Pemasaran $(\mathrm{Rp} / \mathrm{kg})$

$\mathrm{Kp}=$ Keuntungan Pemasaran $(\mathrm{Rp} / \mathrm{kg})$

\section{Farmer Share}

Analisis farmer's share bermanfaat untuk mengetahui bagian harga yang diterima oleh petani dari harga di tingkat konsumen yang dinyatakan dalam persentase (\%). Farmer share diformulasikan sebagai berikut (Sudiyono, 2002) :

Keterangan :

$$
F s=\frac{P f}{P r} \mathrm{X} 100 \%
$$

Fs $=$ Farmer's share

$\mathrm{Pf}=$ Harga di tingkat produsen/petani $(\mathrm{Rp} / \mathrm{kg})$

$\operatorname{Pr}=$ Harga di tingkat konsumen $(\mathrm{Rp} / \mathrm{kg})$

\section{HASIL DAN PEMBAHASAN}

\section{Saluran Pemasaran Tandan Buah Segar Kelapa Sawit di Kecamatan Putri Hijau}

Saluran pemasaran (Channel of distribution) adalah lembaga-lembaga yang mempunyai kegiatan untuk menyalurkan atau menyampaikan barang-barang atau jasa dari produsen ke konsumen (Mursid, 1997). Dalam penelitian ini di ambil 2 desa yaitu desa Karang Tengah dan desa Kota Bani. Kedua desa tersebut memiliki pola saluran pemasaran yang sama diantaranya :

a. Saluran pemasaran I : Petani $\rightarrow$ pedagang pengumpul $\rightarrow$ pabrik

b. Saluran pemasaran II : Petani $\rightarrow$ kelompok tani $\rightarrow$ pabrik

c. Saluran pemasaran III : Petani $\rightarrow$ pabrik

Berdasarkan hasil penelitian saluran pemasaran tandan buah segar kelapa sawit di Desa Karang Tengah produsen (petani) menjual produknya secara umum dapat dilihat pada gambar berikut :

III. $8,70 \%$

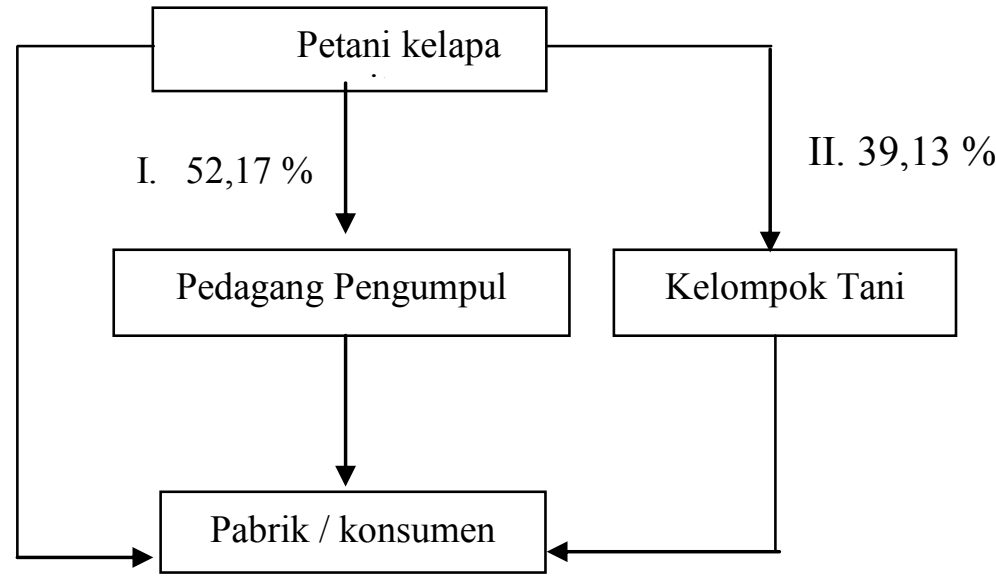

\section{Gambar 1. Skema saluran pemasaran tandan buah segar kelapa sawit Desa Karang Tengah Kecamatan Putri Hijau}

Gambar 1 menunjukan bahwa di Desa Karang Tengah sebanyak 52,17 \% petani menjual tandan buah segar kelapa sawit ke saluran pemasaran I, lalu sebanyak 39,13\% 
petani menjual ke saluran pemasaran II dan sebanyak 8,70 \% petani menjual ke saluran pemasaran III.

Di Desa Karang Tengah pada saluran pemasaran I, terdapat 12 petani atau sebanyak $52,17 \%$ yang menjual TBS kepada 3 pedagang pengumpul dengan jumlah produksi 32.967 $\mathrm{Kg} /$ bulan dengan harga Rp. $1.097 / \mathrm{Kg}$. Pada saluran pemasaran II, terdapat 9 petani atau sebanyak 39,13 \% yang menjual kepada 2 kelompok dengan jumlah produksi 43.197 $\mathrm{Kg} /$ bulan dengan harga Rp. $1.320 / \mathrm{Kg}$. Pada saluran pemasaran III, terdapat 2 petani atau sebanyak 8,70 \% yang menjual TBS langsung ke pabrik dengan jumlah produksi 17.224 $\mathrm{Kg}$ /bulan dengan harga di pabrik Rp. $1.303 / \mathrm{Kg}$.

Berdasarkan hasil penelitian pola saluran pemasaran tandan buah segar kelapa sawit di Desa Kota Bani produsen (petani) menjual produknya secara umum dapat dilihat pada gambar berikut :

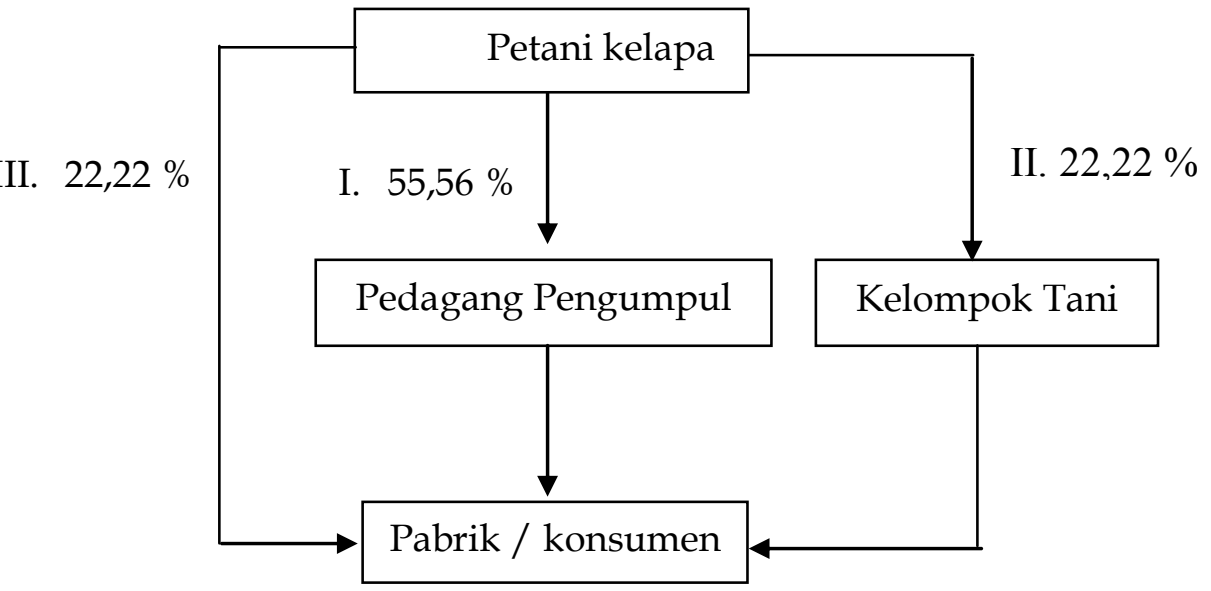

\section{Gambar 2. Skema saluran pemasaran tandan buah segar kelapa sawit Desa Kota Bani Kecamatan Putri Hijau}

Gambar 2 menunjukan bahwa di Desa Kota Bani sebanyak 55,56 \% petani menjual tandan buah segar kelapa sawit ke saluran pemasaran I, lalu sebanyak 22,22 \% petani menjual ke saluran pemasaran II dan sebanyak 22,22 \% petani menjual ke saluran pemasaran III.

Di Desa Kota Bani pada saluran pemasaran I, terdapat 10 petani atau sebanyak $55,66 \%$ yang menjual TBS kepada 3 pedagang pengumpul dengan jumlah produksi $25.090 \mathrm{Kg} /$ bulan dengan harga Rp. $1.097 / \mathrm{Kg}$. Pada saluran pemasaran II, terdapat 4 petani atau sebanyak 22,22 \% yang menjual kepada 1 kelompok dengan jumlah produksi $18.364 \mathrm{Kg} /$ bulan dengan harga Rp. 1.320/Kg. Pada saluran pemasaran III, terdapat 4 petani atau sebanyak 22,22 \% yang menjual TBS langsung ke pabrik dengan jumlah produksi $40.144 \mathrm{Kg} /$ bulan dengan harga di pabrik Rp. 1.303/Kg.

Saluran pemasaran tandan buah segar kelapa sawit yang terjadi didaerah penelitian terlihat didominasi oleh pedagang pengumpul desa, hal ini disebabkan adanya hubungan baik antara petani dengan pedagang pengumpul dan pedagang pengumpul membayar TBS secara tunai, beberapa pedagang pengumpul juga memberikan pinjaman modal kepada petani. Selain itu penjualan TBS ke pedagang pengumpul, petani tidak dipungut oleh biayabiaya pemasaran seperti biaya transportasi, bongkar muat, penimbangan, dll. Petani hanya di kenakan pajak Pendapatan Asli Daerah (PAD) sebanyak 1\% dari hasil produksi, yang akan di berikan ke kantor desa.

Swasta (2002) membedakan saluran pemasaran ke dalam beberapa tingkatan, yakni saluran nol tingkat, saluran setingkat, saluran dwi tingkat, dan saluran tri tingkat. Saluran pemasaran yang terlibat dalam tataniaga tandan buah segar komoditi kelapa sawit umumnya satu tingkat, yakni: Petani $\rightarrow$ Pedagang pengumpul $\rightarrow$ Pabrik Kelapa Sawit (Sumiati, dkk 2017). Namun di daerah lain juga terdapat saluran pemasaran tandan buah 
segar yang lebih kompleks dengan melibatkan lebih banyak pelaku pemasaran, seperti saluran pemasaran tandan buah segar di Kabupaten Kutai Kartanegara yang melibatkan pedagang perantara dan pemilik Surat Pengangkut Buah (pe.SPB) sebagai lembaga pemasaran (Nugroho, 2015).

Petani yang ada didaerah penelitian dalam menjual produknya terbagi menjadi tiga jenis saluran pemasaran, yaitu melalui pedagang pengumpul, kelompok tani dan langsung ke pabrik karena dipengaruhi oleh luas lahan panen, harga TBS dan biaya pemasaran. Transaksi jual beli biasanya dilakukan petani dengan pedagang pengumpul sebelum memanen dengan harapan tandan buah yang sudah di panen nantinya tidak mengalami penimbunan yang terlalu lama. Biasanya petani yang telah melakukan transaksi jual beli dengan pedagang pengumpul sebelum panen maka pedagang tersebut akan menjadi pembeli yang semi permanen artinya pembeli dalam melakukan transaksi tidak berulang setiap mau panen cukup mengetahui tanggal dan waktunya saja.

Pedagang pengumpul TBS kelapa sawit yang ada di daerah penelitian sebanyak 6 orang ini berada di Desa Karang Tengah dan Desa Kota Bani dimana terdapat banyak petani yang melakukan usaha tani kelapa sawit, sehingga pedagang pengumpul dapat dengan mudah mendapatkan tandan buah segar kelapa sawit yang siap ia salurkan kepabrik CPO yang berada di tingkat kecamatan.

Pabrik Crude Palm Oil (CPO) adalah konsumen teratur TBS kelapa sawit, sekaligus sebagai terminal saluran TBS untuk dapat dilakukan pengolahan menjadi minyak mentah. Di Kecamatan Putri Hijau telah dibangun sebuah pabrik CPO diupayakan untuk dapat menampung produksi kelapa sawit rakyat. Di Kecamatan Putri Hijau terdapat tiga perusahaan perkebunan kelapa sawit yaitu PT. Agricinal, PT. Mitra Puding Mas dan PT. Alno Agro Utama, namun dalam penelitian ini petani $100 \%$ menjual hasil produksinya ke PT Agricinal. Hal ini disebabkan karena para petani dan pedagang sudah menjalin hubungan yang baik dengan perusahaan dan juga percaya terhadap harga yang diberikan oleh perusahaan. Selain itu juga masih ada petani yang menjalin kerja sama dengan perusahaan PT Agricinal.

\section{Total Biaya, Margin dan Keuntungan Pemasaran TBS kelapa sawit dalam satu tahun terakhir}

Marjin pemasaran adalah perbedaan harga yang diterima petani dengan yang dibayarkan oleh konsumen akhir, atau perbedaan harga jual dengan harga beli pada tingkat mata rantai pemasaran tertentu. Pada dasarnya marjin pemasaran terdiri atas biaya-biaya yang dikeluarkan oleh petani dan atau lembaga pemasaran dalam melakukan aktifitas pendistribusian TBS kelapa sawit, yang meliputi : biaya transportasi, (pengangkutan), biaya penimbangan, bongkar muat, biaya penyusutan dan pajak daerah. Sedangkan keuntungan pemasaran adalah selisih antara marjin pemasaran dengan biaya pemasaran yang merupakan balas jasa terhadap pedagang yang melakukan aktifitas pemasaran.

\section{Biaya pemasaran}

Biaya pemasaran merupakan komponen yang terpenting dalam margin pemasaran. Dalam penelitian ini biaya pemasaran merupakan semua biaya yang dikeluarkan pada pendistribusian tandan buah segar kelapa sawit dari petani sampai ke konsumen pabrik (pabrik CPO). Penyebaran biaya pemasaran pada lembaga pemasaran pedagang pengumpul dengan kelompok tani berbeda, pedagang pengumpul akan menanggung semua biaya pemasaran. Biaya pemasaran menjadi beban pada lembaga pemasaran yang bersangkutan, dimana besar kecil nya biaya pemasarannya akan sangat tergantung dengan aktifitas masing-masing pedagang pengumpul tersebut, artinya petani tidak menanggung beban 
biaya pemasaran. Besarnya biaya yang dikeluarkan oleh pedagang pengumpul pada setiap desa juga berbeda - beda, ini di sebabkan karena jarak ke pabrik yang berbeda dan infrastruktur jalan yang buruk. Berbeda halnya yang terjadi pada produsen/petani yang menjual ke kelompok tani atau langsung menjual produknya ke pabrik CPO, mereka akan menanggung penentuan biaya transportasi kepabrik sekaligus dengan biaya-biaya yang melekat padanya.

\section{Biaya Petani Kelapa Sawit}

Analisis terhadap biaya oleh petani ini untuk mengetahui berapakah biaya yang di keluarkan petani dalam memasarkan TBS melalui lembaga lembaga pemasaran terkait. Biaya rata-rata pemasaran petani kelapa sawit dapat dilihat pada tabel 2.

Tabel 2. Biaya rata-rata pemasaran petani kelapa sawit

\begin{tabular}{|c|c|c|c|c|c|}
\hline \multirow[b]{2}{*}{ No } & \multirow[b]{2}{*}{ Jenis biaya } & \multicolumn{2}{|c|}{ Desa Karang Tengah } & \multicolumn{2}{|c|}{ Desa Kota Bani } \\
\hline & & $\begin{array}{c}\text { Pengumpul } \\
\text { (Rp/kg) }\end{array}$ & $\begin{array}{l}\text { Kel Tani } \\
\text { (Rp/Kg) }\end{array}$ & $\begin{array}{l}\text { Pengumpul } \\
(\mathrm{Rp} / \mathrm{kg})\end{array}$ & $\begin{array}{l}\text { Kel Tani } \\
\text { (Rp/Kg) }\end{array}$ \\
\hline 1 & Tenaga Kerja & 200,00 & 214,00 & 150,00 & 164,00 \\
\hline 2 & Transportasi & - & 110,00 & - & 60,00 \\
\hline 3 & PAD & 10,97 & 13,20 & & 13,20 \\
\hline 4 & Iuran & - & 19,87 & - & 13,20 \\
\hline & Jumlah & 210,97 & 357,07 & 150,00 & 250,40 \\
\hline
\end{tabular}

Sumber: data primer diolah 2016

*Biaya tenaga kerja terdiri dari biaya panen, nimbang dan bongkar muat

Tabel 2 menunjukan Petani yang menjual produknya melalui pedagang pengumpul atau kelompok tani, di kedua desa maka bila dilihat dari tabel 2, biaya pemasaran petani melalui pedagang pengumpul di Desa Karang Tengah adalah Rp. 210,97/kg dan Rp. 150,00/Kg untuk petani yang menjual TBS melalui pedagang pengumpul di Desa Kota Bani, berbedaan tersebut dikarenakan petani di Desa Karang Tengah membayar PAD sebanyak 1\% dari hasil produksi sedangkan petani di Desa Kota Bani Tidak dan biaya untuk pemanenan di desa karang tengah lebih mahal di karenakan infrastruktur jalan usahatani yang kurang baik. Sedangkan biaya pemasaran petani melalui kelompok tani di Desa Karang Tengah yaitu Rp. 357,07/kg, lebih besar bila di bandingkan dengan biaya petani melalui kelompok tani di Desa Kota Bani yaitu Rp 250,40/Kg, hal ini di sebabkan jarak antara Desa Karang Tengah dengan pabrik lebih jauh bila di bandingkan Kota Bani ke pabrik, dan infrastruktur akses jalan di Desa Karang Tengah kurang baik sehingga biaya sewa transportasi di Desa Karang Tengah lebih besar.

\section{Biaya Lembaga Pemasaran}

Biaya lembaga pemasaran merupakan semua biaya yang dikeluarkan oleh lembaga pemasaran dalam pendistribusian tandan buah segar kelapa sawit dari petani sampai ke pabrik CPO. Dalam penelitian ini petani yang menjual produknya melalui pedagang pengumpul atau kelompok tani, di kedua desa maka bila dilihat dari tabel 14, biaya pemasaran pada pedagang pengumpul Desa Karang Tengah yaitu Rp. 136,88/kg, lebih besar bila di bandingkan dengan biaya pedagang pengumpul Desa Kota Bani yaitu Rp 95,08/Kg. sedangkan biaya pemasaran untuk kelompok tani di Desa Karang Tengah adalah Rp. 4,21/kg dan Rp. 6,28/Kg untuk kelompok tani di Desa Kota Bani, hal ini dapat dilihat pada tabel berikut : 
Tabel 3. Biaya rata-rata lembaga pemasaran

\begin{tabular}{llrrrr}
\hline \multirow{2}{*}{ No } & \multirow{2}{*}{ Jenis biaya } & \multicolumn{2}{c}{ Desa Karang Tengah } & \multicolumn{2}{c}{ Desa Kota Bani } \\
\cline { 3 - 6 } & & $\begin{array}{r}\text { Pengumpul } \\
(\mathrm{Rp} / \mathrm{kg})\end{array}$ & $\begin{array}{r}\text { Kel Tani } \\
(\mathrm{Rp} / \mathrm{Kg})\end{array}$ & $\begin{array}{r}\text { Pengumpul } \\
(\mathrm{Rp} / \mathrm{kg})\end{array}$ & $\begin{array}{r}\text { Kel Tani } \\
(\mathrm{Rp} / \mathrm{Kg})\end{array}$ \\
\hline 1 & Penyusutan alat & 0,74 & 0,55 & 0,92 & 0,75 \\
2 & Tenaga Kerja & 20,00 & - & 55,00 & - \\
3 & Transportasi & 110,00 & - & 21,38 & - \\
4 & Penyusutan TBS & 6,14 & 3,66 & 4,75 & 5,53 \\
5 & PAD & - & - & 13,03 & - \\
\hline & Jumlah & 136,88 & 4,21 & 95,08 & 6,28 \\
\hline
\end{tabular}

Sumber: data primer diolah 2016

*Biaya tenaga kerja terdiri dari biaya nimbang dan bongkar muat

Dari tabel 3 terlihat perbedaan biaya pemasaran antara kedua lembaga pemasaran yang diteliti. Perbedaan tersebut dikarenakan pada kelompok tani biaya - biaya pemasaran seperti biaya tenaga kerja, transportasi dan PAD di tanggung oleh petani. PAD merupakan pajak pendapatan asli daerah, di Kecamatan Putri Hijau petani yang memiliki pendapatan melalui perkebunan di wajibkan membayar $1 \%$ dari hasil produksinya kepada pemerintah desa. Biaya tenaga kerja terdiri dari bongkar muat dan nimbang. Petani yang menjadi anggota kelompok tani akan menanggung biaya pemasaran TBS secara bersama. Kelompok tani hanya menanggung biaya untuk penyusutan alat dan TBS. Berbeda dengan lembaga pemasaran pedagang pengumpul, semua biaya pemasaran sudah menjadi beban pedagang sehingga petani tidak perlu lagi mengeluarkan biaya untuk pemasaran TBS mereka.

\section{Analisis margin pemasaran}

Menurut (Azzaino, 1983) marjin pemasaran adalah perbedaan harga yang dibayar oleh konsumen ahir untuk suatu produk dan harga yang diterima petani produsen untuk produk yang sama. Marjin pemasaran termasuk ongkos yang menggerakan produk tersebut dari pintu gerbang petani sampai ketangan konsumen ahir. Marjin pemasaran juga dapat dinyatakan sebagai nilai dari jasa-jasa pelaksanaan kegiatan pemasaran sejak dari tingkat produsen sampai kekonsumen ahir.

Analisis marjin pemasaran dan share harga merupakan salah satu cara yang dapat digunakan untuk mengetahui efisiensi pemasaran. Untuk mengetahui besarnya marjin pemasaran dilakukan penghitungan biaya yang dikeluarkan dan keuntungan lembaga pemasaran yang ikut berperan dalam proses pemasarannya. Analisis margin pemasaran dilakukan berdasarkan harga rata-rata TBS kelapa sawit dari tingkat petani produsen sampai ke pabrik sebagai konsumen akhir. Satuan harga margin pemasaran dihitung dalam satuan $\mathrm{Rp} / \mathrm{Kg}$. Perhitungan total margin, share, rasio keuntungan serta biaya dan keuntungan dari masing-masing lembaga pemasaran dapat dilihat pada tabel 4 . 
Tabel 4. Rata-rata margin pemasaran, biaya pemasaran dan keuntungan pemasaran tandan buah segar kelapa sawit di Kecamatan Putri Hijau

\begin{tabular}{|c|c|c|c|c|c|}
\hline \multirow{2}{*}{$\begin{array}{c}\text { Salura } \\
\mathrm{n}\end{array}$} & \multirow[t]{2}{*}{ Uraian } & \multicolumn{2}{|c|}{ Desa Karang Tengah } & \multicolumn{2}{|c|}{ Desa Kota Bani } \\
\hline & & $\begin{array}{r}\text { Nilai } \\
\text { (Rp/Kg) }\end{array}$ & Share $(\%)^{*}$ & $\begin{array}{r}\text { Nilai } \\
(\mathrm{Rp} / \mathrm{Kg})\end{array}$ & Share $(\%)^{*}$ \\
\hline \multirow{10}{*}{ I } & 1. Petani & & & & \\
\hline & Harga jual & $1.097,00$ & 84,19 & $1.097,00$ & 84,19 \\
\hline & Biaya petani & 210,97 & 16,19 & 150,00 & 11,51 \\
\hline & Penerimaan petani & 886,03 & 68,00 & 947,00 & 72,68 \\
\hline & 2. P. Pengumpul & & & & \\
\hline & Harga beli & $1.097,00$ & 84,19 & $1.097,00$ & \\
\hline & Harga jual & $1.303,00$ & 100,00 & $1.303,00$ & 100,00 \\
\hline & Margin pemasaran & 206,00 & 15,81 & 206,00 & 15,81 \\
\hline & Biaya pemasaran & 136,88 & 10,51 & 95,08 & 7,30 \\
\hline & Keuntungan & 69,12 & 5,30 & 110,92 & 8,51 \\
\hline \multirow{10}{*}{ II } & 1. Petani & & & & \\
\hline & Harga jual & $1.320,00$ & 100,00 & $1.320,00$ & 100,00 \\
\hline & Biaya petani & 357,07 & 27,05 & 250,40 & 18,97 \\
\hline & Penerimaan petani & 962,93 & 72,95 & $1.069,60$ & 81,03 \\
\hline & 2. Kelompok Tani & & & & \\
\hline & Harga beli & $1.300,80$ & 98,55 & $1.306,80$ & 99,00 \\
\hline & Harga jual & $1.320,00$ & 100,00 & $1.320,00$ & 100,00 \\
\hline & Margin pemasaran & 19,20 & 1,45 & 13,20 & 1,00 \\
\hline & Biaya pemasaran & 4,21 & 0,32 & 6,28 & 0,47 \\
\hline & Keuntungan & 14,99 & 1,14 & 6,92 & 0,53 \\
\hline \multirow{4}{*}{ III } & 1. Petani & & & & \\
\hline & Harga jual & $1.303,00$ & 100,00 & $1.303,00$ & 100,00 \\
\hline & Biaya petani & 312,89 & 24,01 & 224,95 & 17,26 \\
\hline & Penerimaan petani & 990,11 & 75,99 & $1.078,05$ & 82,74 \\
\hline
\end{tabular}

Sumber : data primer diolah 2016

Keterangan*. Persentase terhadap harga jual lembaga pemasaran

Berdasarkan analisis margin pemasaran, diperoleh margin pemasaran terbesar berada pada saluran 1 (petani - pedagang pengumpul - pabrik) yang ada di Desa Kota Bani yaitu Rp 206,00/Kg atau sebesar 15,81 \% dari harga jual pedagang pengumpul Desa Kota Bani. Besarnya margin pemasaran pada saluran I dikarenakan pedagang pengumpul membeli TBS dari petani dengan harga yang lebih rendah dengan pabrik dan besarnya keuntungan yang ingin diperoleh oleh pedagang pengumpul. Margin pemasaran terkecil berada pada saluran II (petani - kelompok tani - pabrik) di Desa Kota Bani yaitu Rp 13,20 / Kg atau sebesar 1,00 $\%$ dari harga jual. Margin pemasaran yang diperoleh kelompok tani ini di dapat dari iuran dari anggota kelompok tani yang mana margin pemasaran ini digunakan untuk pembiayaan alat, penyusutan TBS, pembangunan infrastruktur jalan dan anggaran untuk pengurus kelompok tani, karena kelompok tani membeli TBS dengan harga yang sama dengan harga pabrik maka kelompok tani tidak mengharapkan keuntungan pemasaran.

Indikator dampak kebijakan pemerintah terhadap output dapat dilihat dengan menggunakan nilai OT (Transfer Output) dan NPCO (Nominal Protection Coefficient on Output). Hasil analisis dengan metode PAM diketahui bahwa nilai OT pada usahatani kelapa sawit adalah 0 , artinya tidak adanya intervensi pemerintah dalam penentuan harga 
TBS, dimana mekanisme harga TBS diserahkan sepenuhnya kepada pasar. Besarnya nilai koefisien nominal protection coeffisien on output (NPCO) pada usahatani kelapa sawit 0,8, artinya kebijakan pemerintah bersifat disinsestif (Aprizal,dkk; 2013).

Dari margin, biaya dan keuntungan pemasaran antara kedua lembaga pemasaran ini dapat dilihat bahwa sistem pemasaran kelompok tani lebih efisien dibandingkan lembaga pedagang pengumpul. Bagi petani, pemasaran melalui kelompok tani lebih menguntungkan. Kelompok tani merupakan lembaga yang dalam usahanya bertujuan untuk meningkatkan kesejahteraan anggotanya, tidak untuk mencari keuntungan seperti pedagang pengumpul. Pedagang pengumpul berusaha membeli TBS dengan harga yang serendah- rendahnya dari harga yang di berikan oleh pabrik, sehingga sistem pemasaran ini tidak efisien.

\section{Keuntungan Pemasaran Tandan Buah Segar}

\section{a. Keuntungan Petani Kelapa Sawit}

Keuntungan petani merupakan penerimaan bersih yang di dapat oleh petani yaitu selisih antara harga jual petani dengan biaya - biaya pemasaran yang dikeluarkan oleh petani tersebut. Keuntungan yang diperoleh masing-masing petani kelapa sawit tersebut adalah Rp. 886,03/ kg atau sebesar $68,00 \%$ untuk petani yang menjual TBS melalui pedagang pengumpul di Desa Karang Tengah, dan untuk petani yang menjual TBS melalui pedagang pengumpul di Desa Kota Bani sebesar Rp. 947,00/Kg atau sebesar 72,68\%. sedangkan untuk petani yang menjual TBS melalui kelompok tani di Desa Karang Tengah adalah Rp. 962,93/ kg atau sebesar 72,95\%, dan Rp. 1.069,60/Kg atau sebesar 81,03\% untuk petani yang menjual TBS melalui kelompok tani di Desa Kota Bani. Dengan demikian terlihat petani yang memiliki keuntungan terbesar adalah petani yang menjual TBS melalui kelompok tani, sehingga saluran pemasaran ini efisien dan menguntungkan petani.

Kisaran nilai farmer share yang diperoleh petani dalam penelitian ini berada dalam rentang nilai 68 - 82 persen. Hasil tersebut tidak jauh berbeda dengan penelitian serupa yang telah dilakukan oleh Nugroho (2015), dimana nilai farmer share yang didapat petani kelapa sawit di Kabupaten Kutai Kartanegara sebesar 76,15\% untuk saluran pemasaran dua tingkat dan $73,53 \%$ untuk saluran pemasaran tiga tingkat.

\section{b. Keuntungan Lembaga Pemasaran}

Keuntungan lembaga pemasaran merupakan selisih antara harga jual dengan biayabiaya yang dikeluarkan oleh masing-masing lembaga pemasaran tersebut. Keuntungan pedagang berbeda-beda antara pedagang yang satu dengan pedagang yang lainnya. Hal ini diduga karena jasa yang telah dilakukan oleh pedagang tersebut berbeda-beda. Di samping itu juga dipertimbangkan pula tingkat resiko yang harus ditanggung oleh masing-masing pedagang, semakin besar resiko yang dihadapi maka pedagang memperbesar keuntungan yang dihadapi maka pedagang cenderung memperbesar keuntungan yang diharapkan. Hal ini digunakan untuk menutup kerugian jika risiko tersebut benar-benar terjadi.

Keuntungan yang diperoleh masing-masing lembaga pemasaran untuk pedagang pengumpul di Desa Karang Tengah sebesar Rp 69,12/Kg atau sebesar 5,30\% dari harga jual pabrik yaitu $\mathrm{Rp} 1.303,00 / \mathrm{Kg}$ dan untuk pedagang pengumpul di Desa Kota Bani sebesar Rp $110,92 / \mathrm{kg}$ atau $8,51 \%$ dari harga jual kepabrik yaitu $\mathrm{Rp} 1.303,00 / \mathrm{kg}$. sedangkan untuk kelompok tani di Desa Karang Tengah adalah Rp 14,99/kg, atau sebesar 1,14 \% dari harga jual ke pabrik sebesar Rp 1.320.00/Kg dan Rp 6,92 atau sebesar 0,53\% untuk kelompok tani di Desa Kota Bani. Dengan demikian terlihat adanya perbedaan tingkat keuntungan antara (dua), lembaga pemasaran yang diteliti, baik itu persentasenya ataupun rupiahnya 
pedagang pengumpul lebih tinggi dari pada lembaga pemasaran kelompok tani. Hal ini terjadi karena pada lembaga pemasaran kelompok tani marjin pemasaran nya lebih kecil dan tidak mengharapkan keuntungan.

\section{SIMPULAN DAN SARAN}

\section{Simpulan}

Saluran pemasaran tandan buah segar kelapa sawit rakyat di Kecamatan Putri Hijau Kabupaten Bengkulu Utara dari petani sampai kekonsumen akhir (pabrik CPO) memiliki tiga pola saluran pemasaran yaitu :

- Dari petani ke pedagang pengumpul lalu ke pabrik

- Dari petani ke kelompok tani lalu ke pabrik, dan

- Dari petani langsung ke pabrik

Hasil analisis margin pemasaran tandan buah segar kelapa sawit di Kecamatan Putri Hijau Kabupaten Bengkulu Utara adalah Rp 206,00/Kg melalui pedagang pengumpul di Desa Karang Tengah, kemudian Rp 19,20/Kg untuk kelompok tani di Desa Karang Tengah. sedangkan di Desa Kota Bani adalah Rp 206,00/Kg untuk pedagang pengumpul dan Rp $13,20 / \mathrm{Kg}$ untuk kelompok tani.

\section{Saran}

Dari kesimpulan di atas terlihat bahwa margin pemasaran melalui kelompok tani lebih sedikit bila dibandingkan dengan pedagang pengumpul, hal ini menggambarkan tingkat efisiensi yang tinggi terjadi pada lembaga pemasaran kelompok tani, maka sebaiknya petani kelapa sawit rakyat di Kecamatan Putri Hijau disarankan untuk menjual tandan buah segar melalui kelompok tani, selain itu sebaiknya kelompok tani memiliki transportasi sendiri sehingga petani tidak mengeluarkan biaya sewa transportasi. Untuk pemerintah sendiri di sarankan untuk memperbaiki infrastruktur seperti jalan guna menekan besarnya biaya- biaya pemasaran tandan buah segar, selain itu sebaiknya di bangun pabrik CPO yang mudah di jangkau supaya petani kelapa sawit di desa terpencil lebih mudah memasarkan produksinya dan mengurangi biaya pemasaran.

\section{DAFTAR PUSTAKA}

[BPS] Badan Pusat Statistik.2013. Statistik Perkebunan Provinsi Bengkulu . Dinas Perkebunan Provinsi Bengkulu.

[BPS] Badan Pusat Statistik.2013. Statistik Perkebunan Kabupaten Bengkulu Utara. Dinas Perkebunan Kabupaten Bengkulu utara.

Aprizal, Putri Suci Asriani, dan Sriyoto. 2013. Analisis Daya Saing Usahatani Kelapa Sawit DiKabupaten Mukomuko (Studi Kasus Desa Bumi Mulya). Jurnal Agrisep. Vol 12 no 2 September: 133 - 146.

Asih Putri. S, 2010. Potensi Konflik Pengembangan Perkebunan Kelapa Sawit. https://annisaafillah.wordpress.com/2010/05/10/potensi-konflik-pengembanganperkebunan-kelapa-sawit-oleh-putri-asih-sulistiyo/. 23 Januari 2016

Azzaino, Z. 1983. Pengantar Tata Niaga Pertanian. Departemen Pertanian Ilmu-Ilmu Sosial Ekonomi. Fakultas Pertanian, IPB. Bogor.

Mursid. M, 1997, Manajemen Pemasaran. Edisi Pertama, Cetakan Kedua, Bumi Aksara, Jakarta.

Nazir. 1988. Metode Penelitian. Gramedia. Jakarta

Nugroho, Agung Enggal. 2015. Analisis Pemasaran Tandan Buah Segar Kelapa Sawit Di Kabupaten Kutai Kartanegara (Studi Kasus Pada Petani Swadaya Kecamatan Muara Muntai). Magrobis Journal. Vol 15 (2) Oktober 2015: 47-56 
Sudiyono. 2002. Pemasaran Pertanian. UMM Press. Malang

Sumiati, Rusida, dan Idawati. 2017. Analisis Saluran Pemasaran Kelapa Sawit Di Desa BakuBaku Kecamatan Malangke Barat Kabupaten Luwu Utara. Jurnal Tabaro: Agricultural Science. Vol 1 No.1 p-ISSN 2580-6165 Mei 2017: 46-58.

Sukiyono Ketut, Indra Cahyadinata, Agus Purwoko, Septri Widiono, Eko Sumartono, Nyayu Neti Asriani and Gita Mulyasari. 2017. Assessing Smallholder Household Vulnerability to Price Volatility of Palm Fresh Fruit Bunch in Bengkulu Province. International Journal of Applied Business and Economic Research. 15(3): 1 - 15.

Swastha, Basu. 1991. Konsep dan Strategi Analisa Kuantitatif Saluran Pemasaran. Yogyakarta (ID). BPFE. 